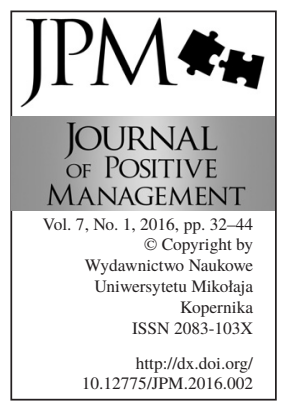

\title{
THE ROLE OF MILITARY LEADERSHIP IN STRATEGIC COMMUNICATION (STRATCOM)
}

\author{
Tomasz Kacała \\ Allied Joint Force Command Brunssum, The Netherlands \\ e-mail: tomasz1975@yahoo.com
}

\begin{abstract}
The aim of the paper is to present the role of military leadership in Strategic Communication (StratCom). The contents of the paper include the major shift in understanding military operations and their environment, the main idea of StratCom and its evolution, and the essential StratCom functional areas. Having the background established, the paper discusses the principle of the key leaders' involvement (engagement). The principle is a fundamental prerequisite for effective StratCom, which proves the importance of military leadership in this field. The paper also includes the practical and theoretical implications referring to the assumptions of the positive management concept.
\end{abstract}

Keywords: strategic communication, military leadership, information environment, principles, key leaders' engagement, positive management

Paper type: General review

\section{Introduction}

Contemporary military operations are conducted in the environment that is characterized by a high degree of complexity and unprecedented multidimensionality. They take many forms and often require an entirely new definition of the scope of activities that are carried out within them. They are, in fact, a manifestation of dimensional shift from the physical impact on the selected objectives to the influence of a non-kinetic character. Twenty-first century conflicts combine elements of different dimensions, including military, political, economic, social, cultural ones and others. The best example of such a conflict is difficult, tense and volatile situation that appeared in Eastern Europe in 2014. The conflict between Russia and Ukraine is the clash of different concepts of functioning of the state in the international environment. The conflict referred to as a "hybrid war" seems to be a phenomenon difficult to master, which entails the involvement of a number of formal and informal factors, and includes the wide use of disinformation and propaganda. These actions are not a new phenomenon in the public space defined in terms of military operations as the information 
environment. The information environment itself provides a new way of perceiving the space defined once as a "battlefield". The latter term turns out to be too narrow and limited in meaning to properly describe the reality of modern conflicts. The information environment is an ideal space to carry out activities of an asymmetric nature that seem to dominate the characteristics of many conflicts emerging recently. Such a changing environment, including the information dimensional dynamics of the public space, forced contemporary decision-makers to take measures to develop a specific system to shape the information environment. An adequate response to the new challenges of the contemporary environment seems to be the concept of Strategic Communication (StratCom). The new concept was based on the assumption of a redefinition of the social communication foundation and taking into account the development of communication techniques. Along with the development and spreading access of a growing number of the process participants, the concept of Strategic Communication developed as well, especially in terms of its essence, the scope of the implemented projects (functional areas involved) and its meaning (role) in the broad sense of non-military and military operations. A number of countries initiated StratCom-related actions by creating their own national solutions which were reflected later on in the relevant Alliance documents published between 2009 and 2010.

From that moment on, Strategic Communication has found its permanent place in all actions taken by the security sector, both internationally and in relation to the internal national system solutions. The Republic of Poland was among the countries that recognized the need to regulate and exploit existing information capabilities in the context of StratCom. It resulted in the development and adoption of The Concept of Strategic Communication in the Polish Armed Forces dated $19^{\text {th }}$ December 2013. The changes made in the Polish Armed Forces' command and control system resulted in modification of the concept. Minister of National Defence implemented them in the form of his decisions in 2014. The changes had no impact on the main idea of the StratCom because its essence was based on the invariable operating principles. One of the basic principles of the concept is the involvement of military leaders in the process of effective Strategic Communication. Properly exercised leadership is the ultimate condition of achieving the desired effect including the required influence results concerning specific audiences and conveying accurate information to the public. It may also be utilised for the purpose of further development of the generally perceived positive management concept, both in its practical and theoretical dimensions.

\section{The main idea of Strategic Communication}

The basic premise underpinning the establishment of measures aimed at achieving the desired level of communication with specific audiences is to redefine and rearrange the processes, resources and capabilities that have long been available in 
THE ROLE

OF MILITARY

LEADERSHIP

Tomasz Kacała

the public space referred to as the information environment. Moreover, it includes capabilities and instruments currently emerging. These elements are coordinated within the framework of Strategic Communication in order to achieve synergy leading then to the proper shaping of the information environment (Kacała, 2012). The main goal of these activities is to achieve the previously accepted political and military objectives. A very important element of StratCom is creation of close relations between the activities of the armed forces and measures implemented by the civil authorities. It includes a number of platforms to include the sphere of Alliance, coalition or Member State activities. Taking into account the information environment's multidimensionality, such factors as the information itself (a specific message), information systems allowing its dissemination (telecommunications infrastructure), and the influence exerted by the message should be considered. An important element of effective StratCom is exertion of certain influence on selected target audiences or conveying messages to specified recipients of communication act. The StratCom results are closely related to the objectives specified during the planning process. Planning activities in the field of StratCom, one should be careful and consider a number of factors that can affect the final result. The complexity of the information environment is expressed, amongst others, in the presence of a very large group of potential recipients. It is particularly important when using the instruments of wide availability such as the Internet. In recent years we have seen the growing role of social media in the wider social communication. Their extensive use by a number of social movements and non-governmental organisations, and even spontaneously formed interest groups resulted in significant political changes initiated in a number of countries (eg. North Africa in 2010). Given the above, maintaining effective StratCom requires strict avoidance of adverse effects and unintended recipients because it can lead to disrupting or even breaking communication with the desired recipient. StratCom, as a concept developed in democratic countries, is in its nature a denial and counterweight of disinformation and propaganda. Hence, it's very important element and fundamental feature is transparency. The conveyed message is, in case of StratCom, based on the truth and real intentions of the sender, regardless of the level applied and the issues concerned. Strategic communication, despite the use of the term "strategic", combines horizontal and vertical influence. The StratCom message goes through communication channels from the highest authorities (decision-makers) to the lowest level of executors and is disseminated by any available and audience-oriented agents. StratCom is a comprehensive communication as it concerns both distributed media functioning outside a given organisation (Alliance, a coalition or state), as well as inside it. It is crucial, in this case, to maintain coherence of conveyed message. It is a condition for its credibility. In conclusion, it should be noted that StratCom is a comprehensive approach to communication as such. It is a process requiring an in-depth analysis 
of the information environment, taking into account all relevant factors influencing this environment and potential changes that may occur in it. Planning activities in the field of StratCom, their implementation and evaluation of their effectiveness in terms of results achieved are a long-term commitment. StratCom is based on the use of the whole range of instruments and capabilities, both those that have a long tradition, as well as the brand new and innovative in nature. StratCom is carried out in a number of dimensions and on various levels. It is often compared to an "orchestra" where appropriate coordination and synchronisation of instruments is the primary factor. The key role in the proper coordination and synchronisation of capabilities and resources remains with the "conductor". He is the guarantor of their transparent, clear and synergistic utilisation, the purpose of which is to achieve synergy. The synergy is not an end in itself and leads to achievement of a certain effect on the audience.

\section{The evolution of StratCom concept}

The first attempts to specify the concept of Strategic Communication were taken at the beginning of the previous decade. The highest level of involvement in this area was presented by the United States of America. In 2006 the U.S. Department of State defined StratCom as "focused United States Government processes and efforts to understand and engage key audiences to create, strengthen, or preserve conditions favourable to advance national interests and objectives through the use of coordinated information, themes, plans, programs, and actions synchronised with other elements of national power" (QDR, 2006). At the same time other definitions of StratCom appeared. Some of them indicated the duality of the idea in the context of both the transmission of information, as well as actions taken to shape the image of a country and some potential opportunities relating to the implementation of political guidance, decision-making process, dissemination of reliable information on the decisions taken and following actions, as well as extremely important, culturally adjusted communication with audiences (see Stavridis, 2007). A kind of synthesis concerning the spectrum of emerging trends in the field of StratCom defined it as a "function to integrate coalition information activities in order to advance coalition interests and objectives, and to promote the coherence of the coalition" (StratCom in MCOWCA, 2009).

Another milestone in the development of StratCom concept was NATO Strategic Communications Policy promulgated in September 2009. Publishing the Policy, the Alliance thus confirmed that it recognises the importance of adequate, timely, accurate and active way of communicating the evolving role of the organisation, its main goals and supporting tasks to be conducted. StratCom was recognised as an integral part of the Alliance's efforts to achieve their political and military objectives. The document clearly defined the requirement to use the full spectrum of NATO information channels available, both traditionally defined 
THE ROLE OF MILITARY LEADERSHIP

Tomasz Kacała media as well as those based on the Internet technology. Moreover, it emphasised the direct involvement of the public opinion in order to make the recipients aware, understand and consequently support the decisions taken by the Alliance and the operations that are the consequence of those decisions. As any actions deliberately undertaken by the Alliance in the sphere of information, StratCom requires internally consistent approach, continuous coordination of efforts taken by Member States and all institutional stakeholders in accordance with the policy adopted by NATO, the relevant rules and procedures. NATO StratCom features specified in the document included technological innovation, active engagement and responsiveness to changes in the information environment in all its dimensions and on every level, consistency and the maximum possible transparency of actions taken. The essence of the new NATO StratCom policy implementation was to raise the level of cohesion of the Alliance social communication mechanisms, both military and civilian, to improve the way NATO communicates with its audiences and other international bodies, and organisations, as well as the optimal use of its resources. Innovation of the Policy was expressed in the specific role attributed to electronic communication. It recognized the importance of the latest technology achievements in the process of gaining advantage in the information environment. The use of such means of communication involves not only the opportunities but also certain challenges. NATO Strategic Communications Policy is a document presenting a general idea, which results from the nature of this kind of allied documents. It sets out the framework, shows the general assumptions and direction for further development of the described concept. It does not solve any potential problems and doubts but recognises the main idea of the StratCom process, provides key definitions and components, as well as defines the purpose, principles and relations among the key structures of command and control/ management system including scopes of their responsibilities in the subject matter.

The result of initiating the process of modifying the StratCom concept, particularly in terms of the tasks arising from the scope of responsibilities of the various structural bodies, was the publication of another important document titled ACO Directive - ACO Strategic Communications. The purpose of this document was to present guidelines for planning and carrying out actions in the field of StratCom within the framework of Allied Command Operations. A significant element of the Directive's added value, which was the next stage of StratCom concept development, consisted in describing the key challenges the Alliance is facing in the contemporary information environment. It clearly indicated the use of information as a weapon of a potential enemy and its impact on the parties involved in a conflict. The situation in which the challenges of this kind take on a specific role is occurrence of the environment of asymmetric threats. Another 
important challenge is to maintain the support of own public opinion and the elements (individuals) forming this opinion in relation to the activities carried out by NATO. StratCom is supposed to enable a proper understanding of the steps taken by NATO forces on behalf of that public opinion in the framework of its operations. According to the Directive, StratCom plays the key role during all phases of an operation and in managing the perception of the actions taken. Strategic Communication also brings its direct contribution to the success of the activities carried out by ACO through the integration of all aspects of operational planning and even NATO policy planning in the subject matter area as well as to properly coordinated implementation of planned undertakings.

The last of the relevant, currently valid, documents is NATO Military Concept for Strategic Communications developed by Allied Command Transformation and published in 2010. It is the most comprehensive StratCom-related document developed so far by the Alliance. The Concept is a summary of previously developed StratCom solutions. It clearly defines StratCom links with the communication strategy approved the North Atlantic Council and thus adopted for the implementation. It indicates the coordinating nature of Information Operations and at the same time stresses the need for independency of those operations and activities conducted by Public Affairs structures. In addition, the document mentions again the need for integration of both planning and implementing StratCom activities in the context of military operations. It also emphasises the importance of military leadership and responsibility of leaders for communicating properly with audiences at all levels. Moreover, the document draws attention to the need to modify existing organisational structures as it is recommended in the case of organisational changes resulting from the adoption of the Alliance Network-Centric Operations' concept. The significant modification of the previous initiatives consisted in placing the emphasis on the need for the delegation of authority in the field of StratCom (dissemination of information based on words, sounds and images) to the lowest possible level in the chain of command. The concept devotes a lot of attention to the capabilities conditioning StratCom and an adequate level of personnel training in terms of competence as well as development and the capability building. NATO Military Concept for Strategic Communications is another step towards the construction of the real Alliance potential in the area of StratCom. It points to the key role played by the armed forces in the field of tasks implementation, especially at the lower levels of command. StratCom is the key element in a wide range of undertakings implemented in order to reach selected audiences with a specific, consistent message supporting the goals and interests of the Alliance. The structures that play the essential role in the NATO StratCom capability building include Allied Command Operations and Allied Command Transformation. 
Tomasz Kacała

\section{Characteristics of StratCom functional areas}

StratCom, regardless of the applied definitions, includes activities coordinated in the sphere of information. In 2004, the U.S. Department of Defense defined StratCom as a combination of the following elements: Information Operations (Info Ops), Public Diplomacy, International Broadcasting Services and Public Affairs (Report, 2004). Whereas NATO Strategic Communications Policy listed Public Diplomacy, Public Affairs, Military Public Affairs, Info Ops and Psychological Operations (PSYOPS). ACO Directive - ACO Strategic Communications refers to StratCom being a composition of Military Public Affairs, Info Ops and PSYOPS coordinated with other military activities. Two of the StratCom elements - Public Affairs and Public Diplomacy - were excluded from the jurisdiction of ACO. NATO Military Concept for Strategic Communications did not make any significant changes referring to the five major functional areas identified in previous publications of the Alliance.

\subsection{Public Diplomacy}

According to a Library of Congress study of U.S. international and cultural programs and activities prepared for the Committee on Foreign Relations of the U.S. Senate, the term Public Diplomacy was first used in 1965 by Dean Edmund Gullion of the Fletcher School of Law and Diplomacy at Tufts University. It was created with the establishment at Fletcher of the Edward R. Murrow Center for Public Diplomacy. Publications of this period stated that Public Diplomacy consists in influencing certain social attitudes and the development and implementation of foreign policy. It included "dimensions of international relations beyond traditional diplomacy; the cultivation by governments of public opinion in other countries; the interaction of private groups and interests in one country with those of another; the reporting of foreign affairs and its impact on policy; communication between those whose job is communication, as between diplomats and foreign correspondents; and the processes of inter-cultural communications" (Origins, 2015).

\subsection{Public Affairs and Military Public Affairs}

The concept of Public Affairs refers to the activities in the socio-political area and the tasks focused on creating the image of a company. It includes building good relations with the environment in such areas as politics, religion, education, government or healthcare. It results from the fact that the techniques of Public Affairs are supposed to have impact on people and the environment they function in. Public Affairs are a derivative of Public Relations. The classic definition of Public Affairs refers to building relations with the opinion-making environment of communication stakeholders. Public Affairs means are the tools to create new markets, to reduce the costs of produced goods and provided services, and to build 
their position on the market. On the other hand, the benefit of Public Affairs for the public sector consists in creation of a broad awareness of social services and provision of social support for state institutions (Lipińska and Kacała, 2014).

Military Public Affairs defines activities aimed at building mutually beneficial relations among troops and the institutions of public sector. The U.S. definition of the concept narrows its meaning to the activities conducted in terms of media involvement on social issues. The U.S. term is synonymous with the term used in Poland for Media Relations (Lipińska and Kacała, 2014).

\subsection{Information Operations (Info Ops)}

According to US Department of Defense, InfoOps are characterized as "the integrated employment, during military operations, of information-related capabilities in concert with other lines of operation to influence, disrupt, corrupt, or usurp the decision making of adversaries and potential adversaries while protecting our own" (JP 3-13, 2014). Considering allied publications, the first document referring to the subject matter, MC 422/3 NATO Policy on INFO OPS of 2007, defined InfoOps as "a military function to provide advice and coordination of military information activities in order to create desired effects on the will, understanding and capability of adversaries, potential adversaries and other North Atlantic Council approved parties in support of Alliance mission objectives" (MC 422/3, 2007). The definition was repeated in AJP-3.10 Allied Joint Doctrine for Information Operations promulgated in 2009 and in NATO Bi-SC Information Operations Reference Book in 2010.

\subsection{Psychological Operations (PSYOPS)}

The definition of Psychological Operations proposed by a number of publications specifies that they are "planned activities using methods of communication and other means directed at approved audiences in order to influence perceptions, attitudes and behaviour, affecting the achievement of political and military objectives" (AJP 3.10.1, 2014). The essence of PSYOPS consists in the fact they are of a long-term nature. Psychological actions may also include ad hoc measures being a response to occurring situations but the overall characteristics of such activities should remain in line with with the general plan of operation. It can be considered that PSYOPS are educational undertakings conducted by the armed forces of democratic countries with the aim of shaping the character of social environment mainly, but not only, in the areas affected by a crisis or an armed conflict (Lipińska and Kacała, 2014).

\section{The military leadership as the fundamental principle of StratCom}

In order to ensure the full integration of the efforts of the armed forces in the domain of information, the military leader should put StratCom (the influence on 
THE ROLE

OF MILITARY

LEADERSHIP

Tomasz Kacała

different groups of audiences) in the centre of all activities. Effective StratCom, expressing the complexity and synergy of actions, words, and images, begins with the presentation of the military leader's clear intention and the issuing of his/ her guidance. This is the basis for the development of a coherent plan including kinetic actions that have the potential to impact the operational environment accompanied by the narration and illustration (words and images). The activities carried out in the various areas of StratCom should be considered by the military leaders as a priority. It means giving the activities conducted in the sphere of communication influence the meaning equivalent of the essential activities carried out by the armed forces (kinetic actions), and incorporating them in all kinds of activities characterizing peacetime, crisis or war. Basically, this kind of commitment refers to the key leaders but operations conducted recently showed that continuous involvement at every level affects the behaviour, attitude and perception of target audiences. This type of activity should be consistent in terms of content (substance), culturally attuned, reliable, adapted to the social reality and intentional (pragmatic).

Involvement of key leaders (Key Leaders' Engagement - KLE) involves the contacts of commanders (military leaders and decision-makers) with the leaders (decision-makers) representing target audiences. The purpose of these contacts is to change behaviour of decision-makers in line with the desired end state of conducted operations. The decision-makers may be local community leaders (formal and informal), religious leaders, academics, etc. An important element of the engagement of this nature is to identify all the key players operating in the area of interest and the relations existing among them. Once key leaders have been identified, they should be analysed in terms of their personality, the leadership style they adopted, the level and scope of their ambition, motives, goals (short and long term), currently presented attitudes, relations (links), psychological profiles and biographies. This is the basis for planning adequate information activities and developing a plan to influence the key leaders, taking into account the situational context, the pre-planned contacts of key personnel with their counterparts representing target audiences, objectives, key messages (topics), desired outcomes and the effectiveness of the influence.

The role of military leaders is not limited, however, to affecting the external environment of an organisation. Equally important, if not more important, is the involvement of military leaders in the proper management of subordinate structures in terms of available human resources, based on specific values. The concept of human resources shall mean all persons involved in the preparation, conduct and evaluation of the StratCom effectiveness and efficiency. Certain values, the principles previously described, underpin effective StratCom. Due to the unique nature of StratCom, involvement of numerous participants and its multidimensionality, the efficient use of the entrusted authority seems to 
be a particular challenge for military leaders. This is particularly important for military structures characterised by an uneven distribution of power (Łydka, 2014).

Military leaders play a very important role in Strategic Communication. They are not only formal superiors, the organisers of the StratCom system and the verifiers of the results achieved. Military leaders are primarily the initiators of the act of communication. It is up to them to actually initiate, continue and develop Strategic Communication activities. They are the true originators of the messages to be disseminated. The structures they supervise are, in fact, a means to achieve the intended objective. A military leader shapes a definite character of StratCom understood as a coordination of individual functional areas (e.g. Public Diplomacy and Public Affairs). Without a real, active and focused leadership one cannot think of any kind of communication, including the strategic one.

The concept of positive management understood as an approach that focuses on positive outcomes within organisations is directly linked with the proper relationship between the employee and employer (Van Elst and Meurs, 2015). The same assumption applies to the role of military leader in the process of Strategic Communication as it is highly dependent on the situational awareness of the various communicators: message originators and message conveyors (distributors). The military "employee" whose responsibility consists in dissemination of StratCom messages to the designated target audiences needs to share the values underpinning the StratCom narrative. He is not just a "tool". His performance should be focused on such positive outcomes as job engagement and self-efficacy that constitute the idea standing behind the concept of positive management (Morrow and Conger, 2015). The positive management, in the military (StratCom) dimension of the concept, should thus be perceived in the two fields of potential development: practical and theoretical. The practical one includes best practices of conveying the designated message/narrative on every level of military operations/ activities (strategic, operational and tactical). The practices should be based on the positive employer (leader) - employee (executor) relations enabling proper understanding of the disseminated message, its form and content. Whereas the theoretical dimension of military-oriented positive management should result in development of appropriate knowledge and expertise considering the precisely defined roles of different level StratCom communicators. It is not about the range of organizational responsibilities (so-called Job Descriptions) but about the role of an individual (or body) in the communication process, its spectrum, environment/surrounding and in relation to any potential threats and challenges (eg. military deception, disinformation and propaganda). As one can find out in the above mentioned documents and papers, there have been a lot actions and efforts undertaken in the field of StratCom conceptual development, especially in the overall "orchestration" field. However, the assumptions of positive management 
Tomasz Kacała should be utilised to further extent in order to make StratCom more effective and successful in the contemporary information environment.

\section{Conclusions}

Contemporary challenges occurring in the information dimension of the operational environment have forced a number of organisations, including the armed forces and their surrounding - defence system of a country, to redefine their approach to social communication understood as reaching out to a selected audience with a specific message. The proposition of solving the problematic situation required formulating the assumptions of the new way of thinking about communication. The new kind of approach to the problem of effective communication assumed the use of functional areas already present in the information space such as Public Diplomacy, Public Affairs, Military Public Affairs, Information Operations and Psychological Operations. The five major functional areas of Strategic Communication were reflected in the documents adopted by the Alliance, which include NATO Strategic Communications Policy (2009), ACO Directive - ACO Strategic Communications (2010), and NATO Military Concept for Strategic Communications (2010).

During the development of the Polish national StratCom concept, certain rules known as the principles were formulated. They include credibility, conciseness, use of dialogue, pervasiveness, synergy, focus on results, proactivity, continuity and direct involvement of military leaders. The last rule is very specific because it conditions the effective Strategic Communication, both in the external and internal dimension. Externally, it refers primarily to the involvement of key leaders consisting in the contacts of military leaders with the decision-makers representing target audiences. The intention involved in the contacts is to change their attitudes and behaviour, including the way of making decisions. A desirable outcome of the actions taken in this regard is to ensure the achievement of the objectives that were determined during the operation planning process.

The internal dimension, very important from the point of view of military leadership, means the commitment of the leaders in the proper management of subordinate structures in terms of available human resources. The management is based on specific values, as well as on the efficient use of the authority entrusted to military leaders who are, in fact, the initiators of the whole process, its key participants and beneficiaries. Ensuring transparency, effectiveness and efficiency of Strategic Communication plays the major role in achieving the objectives of military operations but also in shaping the information environment in the desired manner. Military leaders, being aware and active participants of the StratCom process, enable creation of the conditions required for the subordinate organisation's mission accomplishment, which provides the essence of effective command and control, management and leadership. The positive management 
concept and utilisation of its assumptions, both in theory and practice, may be the key to the successful Strategic Communication in this regard.

\section{References}

AD 95-2 (2009), ACO Strategic Communications, Supreme Headquarters Allied Powers Europe, 19 November.

AJP-3.10 (2009), Allied Joint Doctrine for Information Operations, NATO Standardization Agency, November.

AJP-3.10.1 (2014), Allied Joint Doctrine for Psychological Operations, NATO Standardization Agency, September.

JP 3-13 (2014), Information Operations, U.S. Joint Chiefs of Staff, 20 November, available at: http://www.dtic.mil/doctrine/new_pubs/jp3_13.pdf (accessed 16 March 2015).

Kacała, T. (2012), "Komunikacja strategiczna”, Przegląd Morski, No. 3, pp. 17-27.

Lipińska, J., Kacała, T. (2014), Komunikacja strategiczna i Public Affairs, Wojskowe Centrum Edukacji Obywatelskiej, Warszawa.

Łydka, W. (2014), Przywództwo wojskowe, Wojskowe Centrum Edukacji Obywatelskiej, Warszawa.

MC 422/3 (2007), NATO Military Policy on INFO OPS, NATO Standardization Agency.

Morrow, D., Conger S. (2015), "Exploring Meaningfulness in Work: Why Sensitivity Matters", Journal of Positive Management, Vol. 6 No. 4, pp. 3-14, available at: http://www.jpm.umk.pl/index.php?option=com_content\&view=article\&id=204\&Ite mid=226 (accessed 10 August 2016).

NATO Bi-SC Information Operations Reference Book (2010), NATO.

NATO Military Concept for Strategic Communications (2010), Allied Command Transformation, 27 July.

"Origins of the term Public Diplomacy", available at: http://pdaa.publicdiplomacy. org/?page_id=6 (accessed 31 January 2015).

PO 0141 (2009), NATO Strategic Communications Policy, NATO International Staff, 29 September.

QDR Execution Roadmap for Strategic Communication (2006), U.S. Department of State, Washington DC, available at: http://www.dtic.mil/dtic/tr/fulltext/u2/a495367.pdf (accessed 16 March 2015).

Report of Defense Science Board Task Force on Strategic Communication (2004), U.S. Department of Defense, Washington DC, available at: http://www.dtic.mil/gettr-doc/pdf?AD=ADA476331 (accessed 16 March 2015).

Stankiewicz, W. (2012), "Dyplomacja publiczna - amerykański punkt widzenia”, Historia i Polityka, Vol. 7 No. 14, pp. 101-121, available at: http://apcz.pl/czasopisma/ index.php/HiP/article/view/1475 (accessed 16 March 2015). DOI: http://dx.doi. org/10.12775/1475

Stavridis, J. G. (2007), "Strategic Communication and National Security", Joint Force Quarterly, Vol. 46, pp. 4-7, available at: http://www.dtic.mil/doctrine/jfq/jfq-46.pdf (accessed 16 March 2015).

Strategic Communication in Multinational Coalition Operations Within a Comprehensive Approach. Working Draft. Version 1.0 (2009), Strausberg, 30 November. 
THE ROLE

OF MILITARY

LEADERSHIP

Tomasz Kacała
Van Elst, D., Meurs D. (2015), "Positive Management: The Relationship Between The Psychological Contract, Employee Engagement and Organisational Commitment", Journal of Positive Management, Vol. 6 No. 4, pp. 39-52, available at: http:// www.jpm.umk.pl/index.php?option=com_content\&view=article\&id=207:article81\&Itemid=229 (accessed 10 August 2016). 